may have been inexperienced breeders colonizing a new area (Hamerstrom, 1969, found few nestlings to return), however, of the 15 nests, there were only two nests at which I did not see a defending male, and of the 13 males for which I have records only two were in subadult plumage. There probably were not over two unlocated nests in the study area.

Casual observations of pellets in the field indicated that Marsh Hawks were feeding heavily on the abundant voles. Another factor which perhaps was important in causing them to nest in such concentrations was a fairly large area that was relatively undisturbed by agricultural activities.

There is some evidence that Marsh Hav. ks do not always return in subsequent years to their place of hatching. The third oldest bird from one nest (a male) banded on June 28, 1969 was recovered about mid-September 1970 , some 210 miles northwest (the Kenville area) by L. Mychasiw. Hammond and Henry (1949) reported a direct recovery (i.e., bird recovered the same year as banded) of one bird (from 12 recoveries) having a northerly com- ponent in its direction of movement (800 miles west-northwest). None of the 24 recoveries reported by Houston (1968) had moved north from place of banding to place of recovery.

\section{LITERATURE CITED}

Balfour, E. 1957. Observations on the breeding biology of the Hen-Harrier in Orkney. Bird Notes, $27: 17-183$.

Bird, R. D. 1951. Ecology of the aspen parkland of western Canada. Contribution no. 27, Research Station, Can. Dept. Agri., Winnipeg, $155 \mathrm{pp}$.

Hammerstrom, F. A Harrier population study. In: J. J. Hickey, (Ed.). 1969. Peregrine Falcon populations. Univ. of Wis. Press, Madison, Wisconsin. $596 \mathrm{pp}$.

Hammond, M. C., and C. J. Henry. 1949. Success of Marsh Hawk nests in North America. Auk. $66: 271-274$.

Hecht, W. R 1951. Nesting of the Marsh Hawks at Delta, Manitoba. Wilson Bull. $63: 167-176$.

Hosking, E. J. 1943. Some observations on the Marsh-Harrier. British Birds. $37: 2-9$.

Houston, C. S. 1968. Recoveries of Marsb Hawks banded in Saskatchewan. Blue Jay, $26: 12-13$.

Monthly Recurd, 1968. Meteorological observations in Canada. Meteorological Branch, Department of Transport, Toronto, Ontario.

Sealy, S. G. 1967. Notes on the breeding biology of the Marsh Hawk in Alberta and Saskatchewan. Blue Jay, $25: 63-69$.

Thomson, A. L., (Ed.). 1964. A new dictionary of birds. NicGraw-Hill Book Co., New York. $928 \mathrm{pp}$.

Urner, C. A. 1925. Notes on two sroundnesting birds of prey. Auk, 42-31-41.

\title{
THE RAILWAY - A HAZARD TO BIRDS
}

\section{by W. S. Richards, Saskatoon}

Probably everyone is aware of the incidence of bird mortality due to the collision of birds with vehicles on the highways and with fast-flying jet aeroplanes. Perhaps not so well known is the fact that birds also collide with trains, for dead birds along the railway right-of-way are usually unnoticed.

While working on the Canadian National Railway track I had been casually aware for some time of the dead birds that could be seen beside the track, but I did not think about the cause of their deaths until I became involved in snow-clearing operations during stormy winters. I help operate a railway snow-plow when required. Quite often we have had Gray Partridges fly up in front of the plow and when unable to clear they crash into the side or front of the plow.
Partridges find clear spots on the track and gather there to feed on spilled grain from leaking boxcar doors. In March when Horned Larks are migrating, they too suffer a similar fate. They feed on weed and grass seeds of plants that stick out of the snow along the track. Sometimes at night they seem to be dazzled by the headlight's beam and cannot fly out of the way of the machine. When I was working at the Nutana round-house near the turntable about ten years ago, I recall counting seven dead Horned Larks draped on the front of a diesel locomotive. At other times I remember seeing Gray Partridge and Sharp-tailed Grouse caught in the grill-work and piping. Several years ago at South Saskatoon I found four dead Great Horned Owls within one-quarter of a mile. Other 
species whose death I attribute to collisions with trains are Mallard, Pintail, Blue-winged Teal, American Coot, Mourning Dove, Rock Dove, Blackbilled Cuckoo, Black-billed Magpie, Common Crow, Robin, Mountain Bluebird, Yellow - headed B l a c k b i r d, Meadowlark and Snow Bunting and several unidentified birds, including a large gull, a small owl and a warbler. A dead racing pigeon found near the highway over-pass at the west end of Chappell yards had a band belonging to an Edmonton pigeon club.

Some birds nest in the nooks and crannies of railway cars which are in storage or seldom used. Barn Swallows fly in and out of broken windows in old bunkcars and often nest on any suitable ledge or rafter. Rock Doves also choose similar sites. House Sparrows find many places in which to build their nests and Robins are partial to crossbeams and channel iron. Suddenly they are displaced by the sudden switching of these cars and often the nests are dislodged, resulting in damage to eggs and young. A few years ago at the diesel shop in the Chappell yard in Saskatoon a pair of kingbirds nested in the arch-bars of a set of trucks and as they had to be used, someone relocated the nest in a similar site about 20 feet away. The brood was raised successfully. In the summer of 1968 , while working at Humboldt, we stayed in a bunk car beside a caboose which had not been moved for some time. A pair of Robins had built their nest on a ledge above the caboose door and were busy feeding a youngster. One night both cars were moved about a quarter of a mile away and the young bird could be heard plaintively calling for its missing parents. Before we left in the morning I noticed an adult Robin perched on the roof looking down on the rest but we did not have time for further observations to establish whether this was the actual parent bird.

Another type of fatality I have noticed is "decapitation". Rock Doves commonly feed on grain from boxcars which have leaky doors and I have seen several birds' bodies with heads severed, owing to the unexpected switching of cars. I also saw this hap. pen to a Common Nighthawk, a species which sometimes roosts on the rails in daytime.

There is, however, a "credit" side to the railway location. In many places the railway right-of-way is the last vestige of prairie left in some intensely cultivated area. It is therefore natural habitat for many of our grass sparrows and sometimes the home of the Burrowing Owl. Killdeers choose railway ballast for nesting sites despite passing trains. In dry years railway ditches sometimes retain enough water for a brood of ducks. Rock Doves and Cliff Swallows are at home under trestle and masonry bridges, and hawks, owls and eagles use telegraph poles for perches in treeless areas. Many dams and reservoirs which supplied the water tanks of by-gone days still exist and are used by waterfowl. Thus the railway supplies some encouragement for bird life as well as sometimes causing its destruction.

\section{MILK RIVER VALLEY, ALBERTA, BRIEF EXPLORATIONS}

\section{by Wayne W. Smith, 8220 Elbow Drive, Calgary 9, Alberta}

During the summer of 1971 I was employed in the Cypress Hills Provincial Park of Alberta. Since the Milk River is only about 60 miles away, I made five day-long excursions to the Milk River Valley south of Onefour and Manyberries, Alberta.
Some people are impressed by mountains. The Milk River Valley has much the same impressive aspect, being in effect an inverse mountain range. To me the Milk River Valley was close to a wilderness, though cattle grazing the area are damaging the land; human 